\section{Variations in the Levels of Androgens and Gonadotrophic Hormones in the Blood of Rats during Healing of Fractures}

Testosterone and similar androgens promote the anabolism of proteins. Retention of nitrogen was observed after administration of androgens to gonadectomized animals ${ }^{1,2}$. Male sex hormones also act directly on the skeleton. They enhance endochondrial ossification ${ }^{3}$ and increase metaphyseal growth ${ }^{4}$. They also increase the fusion of osteocartilagenous and bone grafts in rats and accelerate ostoogenic reactions in the surrounding tissues ${ }^{5}$.

In the investigation reported here an attempt was mado to obtain a picture regarding the changes in the levols of androgens, luteinizing and folliclo-stimulating hormones in the blood of rats during the course of healing of fractures.

Mature male rats of an average weight of $200 \mathrm{~g}$ were used. They were divided into groups of 10 animals each. One group of normal intact rats served as control. The remaining groups were subjected to experimental fractures of the left tibiæ. The operations were performed by a closed mothod under ether anæsthesia ${ }^{6}$. A time-table was arranged so that at the end of the experiment the rats wero killed at intervals of $5,10,15,22$ and 29 days after fracture. Blood was collected soparately and the sera belonging to animals of the same group were pooled.

In order to extract androgens from the sera, 4 volumes of acetone wero added. The mixture was then centrifuged at 4,000 r.p.m. for $15 \mathrm{~min}$. The supernatant fraction containing androgens was collected. The precipitated proteins containing gonadotrophins were washod three times with acetone-ether mixture (equal parts by volume) to complete the extraction of androgens, and the washings added to the previously obtained acetone extract. After evaporation of the solvent the extracted androgens were dissolved in cotton soed oil to bring them to the original volume of serum. The protein fraction was also dissolved in saline to restore the original volume?

Androgens were assayed using the chick-comb-growth method $^{8}$. Lutoinizing hormone (LH) contents of $0.5 \mathrm{ml}$. serum of rats was determined by the method depending on the formation of corpora hamorrhagica in the ovaries of immature mice proviously treatod with pregnwant mare serum ${ }^{2}$. Follicle-stimulating hormone content of $0.5 \mathrm{ml}$. of rat serum was determined by the method based on the augmentation reaction of human chorionic gonadotrophin ${ }^{10}$.

Table 1. ANDROGRNs, LUTEINIZING (III) AND FOLLICLE-STIMULA'TING (F'H) HORMONES IN RATS' SERUM DURING FRACTURE HEALING

\begin{tabular}{|c|c|c|c|}
\hline $\begin{array}{l}\text { Days after } \\
\text { fracture }\end{array}$ & $\begin{array}{l}\text { Chick comb-wt. } \\
\text { mg/100 g body-wt. } \\
\text { (androgen) }\end{array}$ & $\begin{array}{c}\text { Corpora } \\
\text { hæmorrhagica/ } \\
\text { mouse (LH) }\end{array}$ & $\begin{array}{c}\text { Ovary-wt. } 100 \mathrm{~g} \\
\text { body-wt. } \\
\text { (FSH) }\end{array}$ \\
\hline $\begin{array}{l}\text { No fracture } \\
\text { (Normal }\end{array}$ & & & \\
\hline control) & $19 \cdot 28 \pm 0 \cdot 97$ & $0.88 \pm 0.22$ & $14 \cdot 45 \pm 1 \cdot 63$ \\
\hline 5 days & $22.06+0.91$ & $1.88 \pm 0.39$ & $14 \cdot 59 \pm 1 \cdot 95$ \\
\hline 10 diays & $21 \cdot 86+1 \cdot 76$ & $0 \cdot 75+0 \cdot 16$ & $16.50+0.89$ \\
\hline & $23.80^{*} \pm 1.62$ & $0.71 \pm 0.28$ & $22 \cdot 68 \pm 1.78$ \\
\hline 22 days & $23 \cdot 69^{*}+1 \cdot 17$ & $0.38 \pm 0.18$ & $16 \cdot 72+1 \cdot 50$ \\
\hline 29 days & $18 \cdot 82 \pm 1 \cdot 77$ & $0.50 \pm 0.27$ & $16 \cdot 29 \pm 1 \cdot 63$ \\
\hline
\end{tabular}

* Signiflcantly different from normal, $P=0 \cdot 05$.

The rosults (Table 1 ) show that there was a statistically significant increase in the comb-weights of chicks treated with androgens extracted from the sora of rats 15 and 22 days after fracture over the comb-weights of chicks treated with serum of normal rats. The level of luteinizing hormone showed a significant increase 5 days after the fracturo. Minimal levels of this hormone were observed during the third and fourth weeks. A statistically high levol of follicle-stimulating hormone was detected in the blood of rats 15 days after the fracture, otherwise the values recorded for this hormone remained within normal levels.

Increasod formation of cellular protoins is essential for the normal process of fracture hoaling. As proviously mentioned, androgens play an important part in protein anabolis $\mathrm{m}^{1,2}$. It has been demonstrated that there is an increased uptake of sulphur-35 by rat humerugl1 and tibia ${ }^{6} 2-3$ woeks after fracturo. This time corresponds to the period of maturation of the cellular elements of the fracture callus ${ }^{6}$. The level of androgens, in the serum, increased at the same period of cellular activity.

The principal action of luteinizing hormones on the testis is to cause the secretion of testicular hormones. Such an increase in the levol of androgens is apparently a result of increased production of pituitary luteinizing and follicle-stimulating hormones. It has been reported that the effectiveness of luteinizing hormone in activating the interstitial cells of the testis is increased in the presence of folliclo-stimulating hormon $\theta^{12}$ and this may explain the increased level of follicle-stimulating hormone two weeks after the operation.

In conclusion, it is noteworthy that in rats with experimental fractures (but otherwise kept under natural conditions) the level of sorum androgens rises during the second and third woeks post-fracture. The accompanying changes in the levels of luteinizing and follicle-stimulating hormones were, in our opinion, necessary for the stimulation of the testis to increase the production of androgens rather than possessing a direct effect on callus formation.

$$
\begin{aligned}
& \text { A. H. SaID } \\
& \text { F. A. Soltman } \\
& \text { M. S. ABdo } \\
& \text { M. K. Solmua }
\end{aligned}
$$

Departments of Surgery and Physiology,

Faculty of Veterinary Medicine, Univorsity of Cairo.

${ }^{1}$ Kochakian, C. D., Vitamins and Hormones, 4, 255 (1946).

${ }^{2}$ Handelsman, J. R., J. Amer. Geriat. Soc., 8, 478 (1960).

${ }^{3}$ Hublé, J., Acta Endocrinol. (Copenhagen), 23, 95 (1956).

‘ Biagini, R., Atti. Accad. Fisiocr. Siena, 3, 201 (1956),

${ }^{5}$ Cavallero, C., Pini, C. E., and Casella, E., Minerva Chir. (Torino), 15/6, $291(1960)$.

'Said, A. H., thesis, Univ. Ghent (1960).

"Szego, C. M., and Poberts, S., Endocrinol., 41, 322 (1947),

${ }^{8}$ Klempner, E., Hollander, F., Frank, R. T., and Kriss, B., Endocrinol., $31,71(1942)$

- Soliman, W. A., Nature, 185, 321 (1960).

10 Brown, H. S., J. Endocrinol., 13, 59 (1955).

${ }^{11}$ Kowalewski, K., and Morrison, R. T., Canad. J, Biochem. Physiol,, 35, $772(1957)$.

${ }^{12}$ Fraenkel-Conrat, H., Li, C. M., Simpson: M. E., and Evans, H. M., Endocrinol., 27,793 (1940).

\section{PHARMACOLOGY}

\section{Toxic Products in Groundnuts}

THE recent appearance of a report ${ }^{1}$ of a symposium on this subject prompts us to record somo of our observations on alleged uses of groundnuts by an Amerindian tribe in tho interior of British (Guiana. With our children we visited several tribes in this general area during 1961 for the purpose of collecting the natural products used medicinally by the piaimen (medicine-men). All our information concerning groundnuts was obtrined from members of the Wapisiana tribe (Arawakan linguistic family; location: Southern Rupununi savannahs, approximately $2^{\circ} 30^{\prime}$ N., $59^{\circ}$ W.). One of them told us that specially preparcd crushed 'Monart' (that is, tho fruits of Arachis hypogaea L. (identified by kind permission of the Director, Royal Botanic Gardens, Kow)) used to be added to the drink of persons whose conduct was deleterious to the tribe and had the effect of producing insanity and, finally, death. The specific example of Fr. Cary. Elwes, S.J., was quoted.

Study of the journal kept by Fr. Cary-Elwes in his latter days is now in progress ${ }^{2}$ so that following earlier reports ${ }^{3}$ on the hepatotoxicity of groundnuts we inquired whether this activity might explain his condition as deduced from the journal. We were informed ${ }^{4}$ that the evidence indicated that he had died from avitaminosis rather than 